\title{
Fatwa Yusuf Qardawi dan Al-Utsaimin tentang Pengucapan Selamat Natal Perspektif Komunikasi Dakwah
}

\author{
Rozmida Febrianti \\ Universitas Darussalam Gontor \\ rozmidafebrianti@gmail.com
}

\begin{abstract}
Fatwas (legal edicts) have an important role in creating social stability. Social change as a result of cultural dynamics often creates friction in society. Islam as a universal religion with specific guidelines based on the Qur'an and Hadith requires the role of ulama (scholars) to translate socio-cultural transformations in the form of fatwas. Therefore, it can be said that the two scholars, Yusuf Qardawi and Al-Utsaimin, are da'i (inviter) who act as communicators of da'wah and fatwas as the messages of da'wah communication while Muslims are the recipients. In this study, the implication of the fatwa on wishing merry Christmas to non-Muslims in the perspective of da'wah communication is explained thoroughly. The current study employs a Library Research method. The ulama and masyaikhs (experts in Islam) in the fatwa above stated the purpose of ijtihad (independent reasoning) in reviewing fatwas and Islamic law in accordance with the purpose of transcendental communication, a communication that involves humans and their God. Human being is a social creature who cannot live on their own and needs others to maintain their existence.
\end{abstract}

Keywords: Yusuf Qardawi Fatwa, Al-Utsaimin, Da'wah communication.

\section{Abstrak}

Fatwa mempunyai peran penting dalam menciptakan stabilitas sosial. Perubahan sosial sebagai hasil dinamika budaya sering menimbulkan gesekan di masyarakat, Islam sebagai agama universal dengan panduan spesifik berdasarkan Alquran dan Hadis memerlukan peran ulama untuk menerjemahkan transformasi sosiokultural dalam bentuk fatwa. Maka dapat dikatakan dua ulama Yusuf Qardawi dan Al-Utsaimin adalah da'i sebagai komunikator dakwah dan fatwa sebagai pesan komunikasi dakwah sedang umat Islam sebagai penerima. Dalam penelitian ini akan membahas secara mendalam tentang implikasi fatwa terhadap bagaimana hukum mengucapkan natal kepada non muslim dalam perspektif komunikasi dakwah. Metode dalam penelitian ini menggunakan riset kepustakaan (Library Research). ${ }^{1}$ Para ulama dan masyaikh dalam fatwa diatas mengemukakan tujuan dari ijtihad dalam mengulas fatwa dan hukum Islam sesuai dengan tujuan komunikasi transendental yaitu Komunikasi yang melibatkan

\footnotetext{
${ }^{1}$ Nasirudin Al Ahsani, "Moderasi Beragama: Meninjau Hadis-Hadis Hukuman Mati Bagi Orang Murtad," Jurnal Al-Hikmah 18, no. 2 (1 Oktober 2020): 170, https://doi.org/ 10.35719/alhikmah.v18i2.33.
} 
manusia dengan Tuhannya itulah yang sering disebut komunikasi transendental.1 Manusia merupakan makhluk sosial yang tidak dapat berdiri sendiri, ia membutuhkan orang lain untuk mempertahankan eksistensinya.

Kata Kunci: fatwa Dr.Yusuf Qardawi, Al-Utsaimin,Komunikasi dakwah.

\section{Pendahuluan}

Fatwa mempunyai peran penting dalam menciptakan stabilitas sosial. Perubahan sosial sebagai hasil dinamika budaya sering menimbulkan gesekan di masyarakat, Islam sebagai agama universal dengan panduan spesifik berdasarkan Alquran dan Hadis memerlukan peran ulama untuk menerjemahkan transformasi sosio-kultural dalam bentuk fatwa.

Namun tidak sedikit fatwa yang kontroversial yang menimbulkan kegaduhan di masyarakat. Fatwa bagi tradisi umat islam merupakan salah satu media untuk menyampaikan hukum-hukum Islam (shariah) Masyarakat muslim mempunyai kecenderungan untuk bertanya tentang banyak hal, pernikahan, muamalah, jinayah, ibadah dan persoalan-persoalan lainnya. ${ }^{2}$

Dalam aktivitas umat Islam yang masih belum ada hukum jelasnya di dalam al-Qur'an, Sunnah dan ijtihad para imam mujtahid yang terdahulu. Tetapisemua persoalaan kontemporer biasanya dikembalikan lagi kepada keadaan dan suasana tempat dengan menyesuaikan kondisi masyarakat terbaru. Maka untuk memastikan umat Islam dapat melakukan setiap aktivitasnya harus berlandaskan hukum Syara' Hukum-hukum tersebut didapati dari ijtihad para ulama dalam memaknai dalil dari Al-Qur'an dan hadits. Dan ijtihad tesebut disebut fatwa. Segala urusan kontemporer yang tidak mempunyai dalil pasti akan halal dan haramnya maka fatwa akan disampaikan oleh mufti yang kemudian ketetapan hukum tersebut dapat diaplikasikan oleh masyarakat. ${ }^{3}$

Maka pada penelitian ini akan dianalisis secara mendalam persoalan ikhtilaf hukum dari pengucapan selamat natal oleh kaum muslim kepada non muslim. Masih belum didapatkan hukum pastinya. Oleh karena itu Yusuf Qardawi dan alUtsaimin mempunyai pandangan dari dalil Al-Qur'an dan Hadits yang berbeda dari hukum hal tersebut. Melalui kacamata keilmuan komunikasi dakwah. Karena melihat dua ulama besar tersebut adalah, ulama berpengaruh pada umat Islam. Maka dapat dikatakan dua ulama tersebut adalah da'i sebagai komunikator dakwah dan fatwa sebagai pesan komunikasi dakwah sedang umat Islam sebagai penerima. Dalam penelitian ini akan membahas secara mendalam tentang implikasi fatwa

2 Umarwan Sutopo, "DIALEKTIKA FATWA DAN HUKUM POSITIF DI INDONESIA: Meneguhkan Urgensi Dan Posisi Fatwa Di Masyarakat Muslim Nusantara," Justicia Islamica 15, no. 1 (29 Desember 2018): 91, https://doi.org/10.21154/justicia.v15i1.1435.

${ }^{3}$ Hasnan Kasan dan Jasri Jamal, "Fatwa dalam Perundangan Islam dan Fungsinya Menangani Keperluan Hukum Semasa Menurut Siasah al-Syar'iyah," Jurnal Undang-undang dan Masyarakat 7, no. 0 (1 Januari 2003): 91.

158 | Rozmida Febrianti 
terhadap bagaimana hukum mengucapkan natal kepada non muslim dalam perspektif komunikasi dakwah.

\section{Metode penelitian}

Metode dalam penelitian ini menggunakan riset kepustakaan (Library Research). ${ }^{4}$ Sumber utama penelitian ini diambil dari jurnal, dan buku-bukuu terkait yang sesuai dengan keperluan penelitian seperti kitab Ahkamu Ahlidz Dzimmah, Malamih Al mujtama al muslim, dan Majma' Fatawa Fadlilah Asy-Syaikh Muhammad bin Shalih aI-'Utsaimin.

\section{Definisi Istilah}

\section{Fatwa}

Kata fatwa ataupun futya mempunyai kesamaan dengan ifta>', dimana ia adalah masdar dari kata afta, yufti, Ifta'an. Adapun kata futya, ataufatwa adalah isim masdar dari afta, hanya saja kata futya lebihsering digunakan oleh orang Arab sebagaimana yang dinukil oleh Ibn Mandzur dalam lisanya.Pengertian Ifta' secara etimologi adalah al-Ibanah (penjelasan), yaitu memberikan penjelasan kepada orang lain. Atas dasar ini, Ifta' berarti memberikan penjelasan kepada orang lain yang menanyakan suatu hal. Pengertian ini menurut hemat penulis sejalan dengan penjelasan Allah ketika menceritakan tentang kerajaan Ratu Saba' saat menerima surat dari Raja Sulaiman 距.

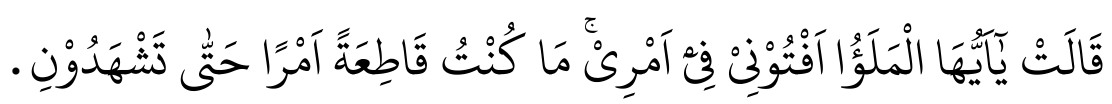

Dia (Balqis) berkata, “Wahai para pembesar! Berilah aku pertimbangan dalam perkaraku (ini). Aku tidak pernah memutuskan suatu perkara sebelum kamu hadir dalam majelis(ku)."

Usamah berpendapat kaitannya dengan ayat di atas bahwa kata aftu>ni bukan bermakna memberikan penjelasan terhadap apa yang ditanyakan oleh Balqis semata-mata, tetapi bermakna permintaan nasehat dan pertimbangan atas suatu perkara yang besar.11 Hal yang senada dengan itu adalah pendapat Ibn Hamdan, bahwa fatwa adalah memberikan keterangan hukum Allah swt berdasarkan dalil Syari', "al-Ikhbar 'anHukmillah bidalilin Syar'iyyin". Ibnu Qudamah dalam Muqaddimah fatwanya mengatakan, bahwa fatwa adalah jawaban dari seorang mufti atas pertanyaan yang disampaikan oleh Mustafti.13 Oleh karena itu

\footnotetext{
${ }^{4}$ Nasirudin Al Ahsani, "Moderasi Beragama: Meninjau Hadis-Hadis Hukuman Mati Bagi Orang Murtad," Jurnal Al-Hikmah 18, no. 2 (1 Oktober 2020): 170, https://doi.org/10.35719/alhikmah.v18i2.33.
} 
penjelasan hukum yang bukan dari pertanyaan maka tidak dinamakan sebagai fatwa, tetapi dinamakan sebagai ta'lim atau al-Irsyad. ${ }^{5}$

\section{Tujuan fatwa}

Terdahulu telah dikemukakan bahwa fatwa mempunyai arti penting dalam hukum Islam. Ia merupakan salah satu sumber materiil hukum Islam di mana melaluinya materi hukum Islam dikembangkan dan menjadi rujukan dalam berbagai masalah agama Islam. Walaupun begitu fatwa tidak memiliki daya ikat seperti daya ikat yang dimiliki oleh putusan hakim. Fatwa merupakan pendapat hukum para fukaha dan bukan keputusan hukum yang mengikat. Namun demikian ia adalah ketentuan hukum Islam seperti ketentuan hukum Islam yang dilahirkan melalui ijtihad para fukaha di luar fatwa. Fatwa adalah bagian integral dari doktrin hukum Islam.

Di Indonesia fatwa tertentu menjadi hukum positif yang berlaku karena diresepsi oleh peraturan perundangan. Fatwa tertentu dimaksud adalah fatwa Majelis Ulama Indonesia (MUI) yang dikeluarkan oleh Dewan Syariah Nasional MUI. Sebagian besar fatwa ini menjadi hukum yang berlaku bagi lembaga keuangan dan bisnis syariah dan menjadi landasan operasional lembaga keuangan syariah. Hal ini dapat dilihat dalam beberapa aspek berikut.

\section{Fungsi fatwa}

Ifta' (pemberian fatwa) mempunyai fungsi penting dalam agama Islam. Ia merupakan penerusan dari fungsi kenabian dalam memberikan bimbingan kepada umat dalam kehidupan mereka. Para ulama dilukiskan oleh Nabi SAW sebagai pewaris para nabi sebagaimana disabdakannya dalam salah satu hadisnya, "Sesungguhnya ulama itu adalah pewaris (orang yang mewarisi) para nabi" [Hadis riwayat Abu Dawud, at-Tirmizi dan Ibn Majah)" Di antara tugas para Nabi yang diwarisi oleh ulama adalah membimbing umatnya dalam masalah keagamaan, dan salah satu bentuknya memberikan penjelasan kepada mereka tentang ketentuanketentuan agama tersebut dalam bentuk fatwa. ${ }^{6}$

\section{Komunikasi dakwah}

Istilah komunikasi dakwah adalah gabungan dari dua kata yaitu, kata komunikasi dan kata dakwah. Istilah komunikasi merupakan kata yang mengandung arti yang lebih lengkap dan luas daripada kata dakwah. Komunikasi adalah proses penyampaian lambang-lambang yang mengandung arti antara satu orang dengan orang lain. Komunikasi adalah bahasa Inggeris communication dari

\footnotetext{
${ }^{5}$ Sutopo, "DIALEKTIKA FATWA DAN HUKUM POSITIF DI INDONESIA," 100.

${ }^{6}$ Prof Dr H. Syamsul Anwar MA, Studi Hukum Islam Kontemporer Bagian Dua (UAD PRESS, 2021), 42.
}

160 | Rozmida Febrianti 
bahasa Latin coomunicatio dan bersumber dari kata communis yang berarti samasama. Sama disini maksudnya adalah sama makna. Menurut terminologi, komunikasi diartikan sebagai proses penyampaian suatu pesan oleh seseorang kepada orang lain untuk memberitahu atau untuk mengubah sikap, pendapat atau perilaku, baik langsung secara lisan, maupun tidak langsung melalui media.

\section{Unsur-unsur komunikasi dakwah}

Faktor yang perlu diperhatikan, yaitu: a. Komunikator dakwah; b. Metode komunikasi dakwah; c. Pesan komunikasi dakwah (isi pesan, corak pesan dan argumentasi pesan komunikasi dakwah); d. Media komunikasi dakwah; e. Penerima. $^{7}$

\section{Hasil dan Pembahasan}

\section{Fatwa hukum mengucapkan selamat Natal.}

Haramnya umat Islam mengucapkan Selamat Natal itu terutama dimotori oleh fatwa para ulama di Saudi Arabia, yaitu fatwa AI-'Alamah Syeikh AIUtsaimin. Beliau dalam fatwanya menukil pendapat Imam Ibnul Qayyim

a. Fatwa Syeikh Al-'Utsaimin

Nama lengkap beliau adalah Abdillah Muhammad bin Shalih bin Muhammad bin Utsaimin Al-Wahib At-Tamimi sedangkan oleh umat Islam dikenal dengan nama Syaikh Ibn Utsaimin atau Syaikh Utsaimin. Beliau dilahirkan di kota Unaizah daerah di Propinsi Qosim Kerajaan Arab Saudi pada malam 27 Ramadhan 1347 H/ 8 Maret $1929 \mathrm{M}$. Beliau dilahirkan dalam lingkungan keluarga yang taat beragama dan dalam lingkungan keluarga yang penuh pancaran ilmu. Kakek beliau dari pihak ibunya yang bernama Syaikh Abdurrahman bin Sulaiman Alu Damigh merupakan salah seorang ulama yang di kenal di daerah Qosim saat itu. Dari geneologis ini dapat diketahui bahwa beliau berasal dari keluarga yang berilmu. ${ }^{8}$

Syaikh Utsaimin kecil mulai belajar membaca Al-Quran kepada kakeknya (ayah dari ibunya) yaitu Syaikh Abdurrahman bin Sulaiman Ali ad-Damigh, hingga beliau hafal. Sesudah itu beliau mulai mencari ilmu dan belajar lahar (ilmu tulis menulis), ilmu hitung, dan beberapa bidang ilmu sastra kepada kakeknya tersebut. Kemudian Syaikh Utsaimin melanjutkan belajarnya di Maktab (sekolah kecil) Syaikh Abdurrahman asa-sa'di, Syaikh Abdurrahma asa-Sa'di. Sebagaimana terdapat dalam kitab Majma' Fatawa Fadlilah Asy-Syaikh Muhammad bin Shalih aI-'Utsaimin, disebutkan bahwa: Memberi selamat kepada mereka hukumnya haram, sama saja apakah terhadap mereka (orang-orang kafir) yang terlibat bisnis

\footnotetext{
${ }^{7}$ Nita Andriani, "Etika Komunikasi Bisnis Dalam Perspektif Islam,” Jurnal Al-Hikmah 19, no. 01 (1 April 2021): 2, https://doi.org/10.35719/alhikmah.v19i01.40.

${ }^{8}$ Saifuddin Amin, Etika Peserta Didik Menurut Syaikh Muhammad Bin Shalih Al-Utsaimin (Deepublish, 2019), 33.
} 
dengan seseorang (muslim) atau tidak. Jadi jika mereka memberi selamat kepada kita dengan ucapan selamat hari raya mereka, kita dilarang menjawabnya, karena itu bukan hari raya kita, dan hari raya mereka tidaklah diridhai Allah. Hal itu merupakan salah satu yang diada-adakan (bid'ah) di dalam agama mereka, atau hal itu ada syari'atnya tapi telah dihapuskan oleh agama Islam yang Nabi Muhammad SAW telah diutus dengannya untuk semua makhluk. ${ }^{9}$

\section{b. Fatwa Ibnul Qayyim}

Dalam kitabnya Ahkamu Ahlidz Dzimmah beliau berkata : Adapun mengucapkan selamat berkenaan dengan syi'ar-syi'ar kekufuran yang khusus bagi mereka adalah haram menurut kesepakatan para ulama. Alasannya karena hal itu mengandung persetujuan terhadap syi'ar-syi'ar kekufuran yang mereka lakukan.

Selain pendapat yang tegas mengharamkan di atas, kita juga menemukan fatwa sebagian dari ulama yang cenderung tidak mengharamkan ucapan tahni'ah kepada umat nasrani. Yang menarik, ternyata yang bersikap seperti ini bukan hanya dari kalangan liberalis atau sekuleris, melainkan dari tokoh sekaliber Dr. Yusuf AlQardawi. Tentunya sikap beliau itu bukan berarti harus selalu kita ikuti.

\section{c. Fatwa MUI}

Sedangkan terkait dengan fatwa MUI tentang haramnya mengucapkan selamat natal, ketika mencari dokumennya ternyata kami kesulitan mendapatkannya. Konon kabarnya fatwa itu dikeluarkan pada tahun 1984, seperti yang ada dalam SMS yang kami terima Tetapi setelah dibrowse di situs MUI (www.mui.or.id). ${ }^{10}$

Maupun di buku Kumpulan Fatwa MUI yang kami miliki, fatwa haram itu tidak kami temukan. Yang kami temukan hanyalah fatwa tentang haramnya melakukan natal bersama. Sebaliknya, kami malah mendapatkanberita yang agak kontradiktif dengan apa yang dianggap sebagai sikap MuI selama ini. Sekretaris Jenderal MUI, Dr. Dien Syamsudin MA, yang juga Ketua Umum Pimpinan Pusat (PP) Muhammadiyah itu memang pernah menyatakan bahwa MUI tidak melarang ucapan selamat Natal, tapi melarang orang Islam ikut sakramen (ritual) Natal. "Kalau hanya memberi ucapan selamat tidak dilarang, tapi kalau ikut dalam ibadah memang dilarang, baik orang Islam ikut dalam ritual Natal atau orang Kristen ikut dalam ibadah orang Islam, " katanya. Bahkan pernah di hadapan ratusan umat Kristiani dalam seminar Wawasan Kebangsaan X BAMAG Jatim di Surabaya, beliau menyampaikan, "Saya tiap tahun memberi ucapan selamat Natal kepada teman-teman Kristiani."

\section{d. Fatwa Dr. Yusuf AI-Qardawi}

\footnotetext{
${ }^{9}$ Ahmad Sarwat, "Fiqih Interaksi Muslim Dengan non Muslim," t.t., 33.

10 "Majelis Ulama Indonesia - MUI.OR.ID," diakses 23 Juli 2021, https://mui.or.id/.

162 | Rozmida Febrianti
} 
Yusuf al-Qardawi lahir pada tanggal 9 September 1926, di Desa Safat Turab, Mesir bagian Barat, sebuah lingkungan masyarakat yang terdidik. Nama lengkap Yusuf al-Qardawi adalah Yusuf ibn Abdullah al-Qardawi. Dia berasal dari keluarga yang tekun beragama. Dalam usia dua tahun hidup tanpa bimbingan sang ayah, yang lebih dulu meninggal dunia. Ia menjadi anak yatim yang mulai saat itu diasuh oleh pamannya, Dengan perhatian yang cukup baik dan lingkungan keluarga yang tekun, teguh dan kuat beragama itu, Yusuf al-Qardawi pada umur lima tahun teah memulai hafal Al-Qur'an. Dalam perkembangannya, belum sampai usia 10 tahun ia sudah mampu menghafal Al-Qur'an secara keeluruhan serta fasih bacaannya, karena pengetahuannya tentang tajwid yang sempurna dan merdu pula suaranya. Pendidikan selanjutnya diteruskan ke Ma'had Tanta, yang diselesaikan selama empat tahun, kemudian dilanjutkan pada tingkat menengah yang diselesaikan dalam waktu lima tahun. Dari sinilah al-Qardhawi melanjutkan pendidikan tingkat tingginya dengan memasuki universitas al-Azhar, Kairo untuk mengambil bidang studi agama pada fakultas Ushuluddin sampai mendapat syahadah aliyah (tahun 1952-1953), dengan predikat lulus terbaik. Kemudian pada tahun 1957 al-Qarhawi masuk pada Ma'hadal-Buhus wa ad-dirat al-Arabiyah sehingga mendapatkan diploma tinggi di bidang bahasa dan sastra. ${ }^{11}$

Syeikh Dr. Yusuf AI-Qardawi mengatakan bahwa merayakan hari raya agama adalah hak masing-masing agama. Selama tidak merugikan agama lain. Dan termasuk hak tiap agama untuk memberikan tahni'ah saat perayaan agama lainnya.

Maka kami sebagai pemeluk Islam, agama kami tidak melarang kami untuk untuk memberikan tahni'ah kepada non muslim warga negara kami atau tetangga kami dalam hari besar agama mereka. Bahkan perbuatan ini termasuk ke dalam kategori aI-birr (perbuatan yang baik).

Sebagaimana firman Allah SWT: Allah tidak melarang kamu untuk berbuat baik dan berlaku adil terhadap orang-orang yang tiada memerangimu karena agama dan tidak mengusir kamu dari negerimu. Sesungguhnya Allah menyukai orangorang yang berlaku adil. (QS. Al-Mumtahanah: 8) Kebolehan memberikan tahni'ah ini terutama bila pemeluk agama lain itu juga telah memberikan tahni'ah kepada kami dalam perayaan hari raya kami.

Apabila kamu diberi penghormatan dengan sesuatu penghormatan, maka balaslah penghormatan itu dengan yang lebih baik dari padanya, atau balaslah penghormatan itu. Sesungguhnya Allah memperhitungankan segala sesuatu. (QS. An-Nisa': 86) Namun Syeikh Yusuf AI-Qaradawi secara tegas mengatakan bahwa tidak halal bagi seorang muslim untuk ikut dalam ritual dan perayaan agama yang khusus milik agama lain.

${ }^{11}$ Dina Yustisi Yurista, "Prinsip Keadilan dalam Kewajiban Pajak dan Zakat Menurut Yusuf Qardhawi," Ulul Albab: Jurnal Studi dan Penelitian Hukum Islam 1, no. 1 (31 Oktober 2017): 43, https://doi.org/10.30659/jua.v1i1.1962. 


\section{Analisis fatwa dalam konteks komunikasi dakwah}

Komuniasi Dakwah adalah suatu ilmu yang mempelajari tentang proses komunikasi atau penyampaian pesan dari da'i kepada mad'u. Ilmu Komunikasi memberikan bantuan keilmuan yang integratif dalam memperkaya ilmu dakwah dalam membahas bentuk-bentuk komunikasi. ${ }^{12}$ Maka pada fatwa yang disampaikan oleh masyaikh dan para ulama dikatakan sebagai komunikasi intrapersonal dan interpersonal. Karena para ulama sebagai da'i sekaligus mad'u yang memberikan umpan balik pada diri sendiri dalam proses internal yang berkelanjutan sebagai contoh dalam beribadah dan mencari ilmu. Sedangkan pada komunikasi interpersonal ulama atau masyaikh dikatakan sebagai da'i yang menyampaikan dakwahnya dengan media. Media di sini berupa media tulis dari buku masyaikh tersebut dengan judul kitab Ahkamu Ahlidz Dzimmah dan Kitab Yusuf qardawi Malamih Al mujtama al muslim dalam buku fatwa-tawa kontemporer yang beliau tulis.

Komunikasi merupakan salah satu kebutuhan dasar manusia. Sebab, tanpa komunikasi manusia tidak akan berkembang dan mengenal satu sama lain. Komunikasi pada dasarnya merupakan proses pertukaran simbol yang mengandung makna, yang dengan simbol itu manusia saling berbagi dalam mengirim dan menerima pesan. Secara umum, jenis komunikasi terdiri atas komunikasi verbal dan komunikasi nonverbal. Keduanya selalu digunakan dalam setiap proses interaksi diantara manusia. Komunikasi efektif adalah komunikasi yang menghasilkan efek yang sesuai dengan tujuan komunikasi itu sendiri. Dalam kaitan ini, faktor simbol, media, situasi dan kondisi sangat menentukan keberhasilan komunikasi. Dalam proses pertukaran pesan, komunikasi tidak selalu berjalan mulus atau sesuai dengan apa yang diharapkan. Dalam konteks ini, proses komunikasi selalu dihadapkan pada sejumlah faktor yang seringkali menghambat jalannya proses komunikasi. Hambatan atau gangguan komunikasi itu bisa berupa fisik, psikis, semantik, media dan lain sebagainya. ${ }^{13}$

Para ulama dan masyaikh dalam fatwa diatas mengemukakan tujuan dari ijtihad dalam mengulas fatwa dan hukum Islam sesuai dengan tujuan komunikasi transendental yaitu Komunikasi yang melibatkan manusia dengan Tuhannya itulah yang sering disebut komunikasi transendental.1 Manusia merupakan makhluk sosial yang tidak dapat berdiri sendiri, ia membutuhkan orang lain untuk mempertahankan eksistensinya. Manusia harus membangun hubungan horisontal yakni dengan manusia lainnya dan vertikal dengan Tuhannya. Hubungan itu akan

12 Kamaluddin Ritonga, "Bentuk -Bentuk Komunikasi Dalam Perspektif Dakwah Islam," Tadbir: Jurnal Manajemen Dakwah FDIK IAIN Padangsidimpuan 2, no. 2 (22 Desember 2020): 267.

${ }^{13}$ Ibid., 19.

164 | Rozmida Febrianti 
membawa seorang individu menjadi manusia paripurna. Hubungan dialektis antara dimensi vertikal dan horizontal dapat dijelaskan pula dengan melihat tiga perspektif transendental yaitu penerimaan, respons dan reaksi. Tiga istilah ini merujuk pada sisi kemanusiaan dari pernyataan Ilahi yaitu bahwa manusia melakukan reaksi atas komunikasi dengan dirinya yang telah menerima pesan Tuhan. Jadi dalam perspektif penerimaan manusia dicari Tuhan. Dalam perspektif respons manusia mencari Tuhan, misalnya dalam bentuk doa. Doa dapat dipahami sebagai dialog intrapersonal dengan diri sendiri, di mana misteri diri secara intuitif dialami sebagai tanda komitmen kepada Tuhan. ${ }^{14}$

Pada peneliti ini juga peneliti mengumpulkan beberapa kata atau istilah kunci serta kalimat-kalimat pokok yang terdapat dalam fatwa yang kemudian untuk menjelaskan bahwa peneliti (komunikan) dapat menafsirkan atau memahami secara tepat istilah atau pesan fatwa yang disampaikan oleh komunikator (Ulama dan lembaga fatwa).

\section{Kata Istilah Dalam Fatwa}

\begin{tabular}{|c|c|c|}
\hline No & Kata istilah & Penjelasan \\
\hline 1. & $\begin{array}{l}\text { Fatwa mengucapkan selamat hari } \\
\text { natal menurut Al-Utsaiminadalah } \\
\text { Memberi selamat kepada mereka } \\
\text { hukumnya haram, sama saja } \\
\text { apakah terhadap mereka (orang- } \\
\text { orang kafir) yang terlibat bisnis } \\
\text { dengan seseorang (muslim) atau } \\
\text { tidak. }\end{array}$ & $\begin{array}{l}\text { Fatwa adalah sebuah istilah mengenai } \\
\text { pendapat atau tafsiran pada suatu } \\
\text { masalah yang berkaitan dengan hukum } \\
\text { Islam }\end{array}$ \\
\hline 2. & $\begin{array}{l}\text { Syeikh Dr. Yusuf AI-Qardawi } \\
\text { mengatakan bahwa merayakan } \\
\text { hari raya agama adalah hak } \\
\text { masing-masing agama. Selama } \\
\text { tidak merugikan agama lain. Dan } \\
\text { termasuk hak tiap agama untuk } \\
\text { memberikan tahni'ah saat } \\
\text { perayaanagama } \\
\text { lainnya. }\end{array}$ & $\begin{array}{l}\text { Suatu sikap saling menghormati dan } \\
\text { menghargai antar kelompok atau } \\
\text { individu dalam masyarakat }\end{array}$ \\
\hline
\end{tabular}

Maka dapat disimpulkan bahwa fatwa-fatwa yang disampaikan oleh alUtsaimin dan Yusuf Qardawi dapat dipahami dan fatwa tersebut dapat dijadikan

14 Wahidah Suryani Djafar, "Komunikasi Transendental Manusia-Tuhan," Farabi 12, no. 2 (1 Desember 2015): 151. 
sebagai komunikasi yang efektif.

Komunikasi efektif adalah, interaksi yang diantarkan secara simbolis, menurut bahasa dan mengikuti normanorma. Bahasa harus dapat dimengerti, benar, jujur dan tepat. Keberlakuan norma-norma itu hanya dapat dijamin melalui kesepakatan dan pengakuan bersama bahwa kita terikat olehnya. Interaksi komunikasi mengembangkan kepribadian orang, melalui internalisasi peran-peran sosial. Komunikasi yang salah diganjari sanksi. Sebelumnya Habermas menjelaskan bahwa di dalam komunikasi itu, para partisipan membuat lawan bicaranya memahami maksudnya dengan berusaha mencapai apa yang disebutnya. "klaim-klaim kesahihan (validity claims), yang terdiri atas

1. Klaim kebenaran ( truth ), ini akan tercapai apabila masing-masing diri kita dapat bersepakat tentang dunia alamiah dan obyektif,

2. Klaim Ketepatan (raightness), ini akan tercapai kalau sepakat tentang pelaksanaan norma-norma dalam dunia sosial,

3. Klaim otentitas atau kejujuran (sincerety), akan tercapai kalau sepakat tentang kesesuaian antara dunia batiniah dan ekspresi seseorang,

4. Klaim comprehensibilitas (compreshensibility) akan tercapai jika kita dapat menjelaskan macam-macam klaim itu dan mencapai kesepakatan atasnya.

Setiap komunikasi yang efektif perlu mencapai klaim-klaim tersebut, dan orang-orang yang mampu berkomunikasi dalam arti menghasilkan klaim-klaim itu, disebutnya memiliki "kompetensi komunikatif". Masyarakat komunikatif adalah masyarakat yang melakukan kritik melalui argumentasi. Klaim-klaim di atas oleh Habermas dipandang sebagai rasional dan akan diterima tanpa paksaan sebagai hasil konsensus. ${ }^{15}$

Menyatakan bahwa faktor penting dalam komunikasi efektif tidak hanya terfokus pada berbicara atau penyampaian pesan yang efektif, tetapi juga mendengarkan yang efektif. Dalam model komunikasi convergen semua pihak yang terlibat akan melakukan tukar pikiran menuju pemahaman bersama, disini berbicara dan mendengar jelas sama-sama pentingnya. Inilah sisi penting belajar mendengarkan yang efektif.Seperti halnya di dalam hidup, dalam komunikasi pun berbicara dan mendengarkan hendaknya didudukan dalam posisi yang seimbang. Banyak faktor atau kondisi (moment) yang memungkinkan kapan seseorang berbicara dan kapan seseorang mendengarkan secara efektif.

\section{Kesimpulan}

Fatwa mengucapkan selamat hari natal menurut Al-Utsaiminadalah Memberi selamat kepada mereka hukumnya haram, sama saja apakah terhadap mereka (orang-orang kafir) yang terlibat bisnis dengan seseorang (muslim) atau tidak. Jadi

15 Richard West dan Lynn H. Turner, Pengantar Teori Komunikasi 2 (Jakarta: Salemba Humanika, 2008), 18.

166 | Rozmida Febrianti 
jika mereka memberi selamat kepada kita dengan ucapan selamat hari raya mereka, kita dilarang menjawabnya, karena itu bukan hari raya kita, dan hari raya mereka tidaklah diridhai Allah. Hal itu merupakan salah satu yang diada-adakan (bid'ah) di dalam agama mereka, atau hal itu ada syari'atnya tapi telah dihapuskan oleh agama Islam yang Nabi Muhammad SAW telah diutus dengannya untuk semua makhluk. ${ }^{16}$

Sedangkan Fatwa mengucapkan selamat hari natal kepada non muslim menurut Yusuf Qardawi mengatalan bahwa apabila kamu diberi penghormatan dengan sesuatu penghormatan, maka balaslah penghormatan itu dengan yang lebih baik dari padanya, atau balaslah penghormatan itu. Sesungguhnya Allah memperhitungankan segala sesuatu. (QS. An-Nisa': 86) Namun Syeikh Yusuf AIQaradawi secara tegas mengatakan bahwa tidak halal bagi seorang muslim untuk ikut dalam ritual dan perayaan agama yang khusus milik agama lain.

Para ulama dan masyaikh dalam fatwa diatas mengemukakan tujuan dari ijtihad dalam mengulas fatwa dan hukum Islam sesuai dengan tujuan komunikasi transendental yaitu Komunikasi yang melibatkan manusia dengan Tuhannya itulah yang sering disebut komunikasi transendental.1 Manusia merupakan makhluk sosial yang tidak dapat berdiri sendiri, ia membutuhkan orang lain untuk mempertahankan eksistensinya.

\section{Daftar Pustaka}

Ahsani, Nasirudin Al. "Moderasi Beragama: Meninjau Hadis-Hadis Hukuman Mati Bagi Orang Murtad." Jurnal Al-Hikmah 18, no. 2 (1 Oktober 2020): 16988. https://doi.org/10.35719/alhikmah.v18i2.33.

Amin, Saifuddin. Etika Peserta Didik Menurut Syaikh Muhammad Bin Shalih AlUtsaimin. Deepublish, 2019.

Andriani, Nita. "Etika Komunikasi Bisnis Dalam Perspektif Islam." Jurnal AlHikmah 19, no. 01 (1 April 2021): 13-26. https://doi.org/10.35719/alhikmah.v19i01.40.

Djafar, Wahidah Suryani. "Komunikasi Transendental Manusia-Tuhan.” Farabi 12, no. 2 (1 Desember 2015): 150-63.

Kasan, Hasnan, dan Jasri Jamal. "Fatwa dalam Perundangan Islam dan Fungsinya Menangani Keperluan Hukum Semasa Menurut Siasah al-Syar'iyah." Jurnal Undang-undang dan Masyarakat 7, no. 0 (1 Januari 2003): 89-111.

MA, Prof Dr H. Syamsul Anwar. Studi Hukum Islam Kontemporer Bagian Dua. UAD PRESS, 2021.

"Majelis Ulama Indonesia - MUI.OR.ID.” Diakses 23 Juli 2021. https://mui.or.id/.

${ }^{16}$ Sarwat, "Fiqih Interaksi Muslim Dengan non Muslim," 33. 
Ritonga, Kamaluddin. "Bentuk -Bentuk Komunikasi Dalam Perspektif Dakwah Islam.” Tadbir: Jurnal Manajemen Dakwah FDIK IAIN Padangsidimpuan 2, no. 2 (22 Desember 2020): 255-68.

Sarwat, Ahmad. "Fiqih Interaksi Muslim Dengan non Muslim," t.t., 54.

Sutopo, Umarwan. "DIALEKTIKA FATWA DAN HUKUM POSITIF DI INDONESIA: Meneguhkan Urgensi Dan Posisi Fatwa Di Masyarakat Muslim Nusantara." Justicia Islamica 15, no. 1 (29 Desember 2018): 87108. https://doi.org/10.21154/justicia.v15i1.1435.

West, Richard, dan Lynn H. Turner. Pengantar Teori Komunikasi 2. Jakarta: Salemba Humanika, 2008.

Yurista, Dina Yustisi. "Prinsip Keadilan dalam Kewajiban Pajak dan Zakat Menurut Yusuf Qardhawi." Ulul Albab: Jurnal Studi dan Penelitian Hukum Islam 1, no. $1 \quad(31$ Oktober 2017): 39-57. https://doi.org/10.30659/jua.vli1.1962. 